\title{
Future of AIDS research office threatened
}

Washington. A US congressional subcommittee has voted to eliminate the researchfunding responsibilities of the National Institutes of Health (NIH)'s fledgling Office of AIDS Research (OAR). The move calls into question the future of the two-year-old office, which is responsible for co-ordinating research on AIDS.

At the same time, the committee has also recommended a 5.7 per cent increase in funding for research at $\mathrm{NIH}$ as a whole, including an 11 per cent increase for human genome research. But some researchers fear that the Republican-dominated Congress is seeking to cut funding for AIDS research, while the overall budget package - which would also abolish the post of Surgeon General - is being opposed by the Clinton administration because of its cuts in social and education programmes.

The AIDS office was set up by Congress in 1993 after researchers and activists had convinced lawmakers of the need for better coordination of AIDS research. Last week's move, taken by an appropriations subcommittee in the House of Representatives, would remove funds for AIDS from William Paul, the director of OAR, and return them to the general funding stream at NIH.

"The bill removes numerous earmarks

\section{Lawyers 'built tobacco smokescreen'}

San Francisco. Last week, the US Food and Drug Administration (FDA) announced its conclusion that nicotine is a drug - and can therefore be legitimately regulated as such. The announcement coincided with the publication of an analysis of tobacco industry documents revealing that industry lawyers have controlled the direction and reporting of both internal and external scientific projects in order to keep knowledge of tobacco's deleterious effects hidden.

The analysis is based on confidential internal documents from Brown \& Williamson Co. and British-American Tobacco Co., and was carried out by researchers at the University of California, San Francisco (UCSF), which had received them from an anonymous source.

The researchers concluded that the lawyers promoted certain research, steered the company away from other work and influenced the ways in which studies were reported, and that their goal was to influence government policy-makers, convince the public that smoking is safe, and develop ammunition for liability suits.

The documents, which UCSF fought to keep in the public domain, were reviewed in detail by UCSF researchers in the 19 July issue of the Journal of the American Medical Association. More than half are directly available on the Internet.

Brown \& Williamson called the articles "a cherry-picking exercise", arguing that it was natural for its lawyers to be involved in defending the company's position. "Brown \& Williamson's lawyers have conducted themselves appropriately," it said.

But Stanton Glantz, a professor of medicine at UCSF, says that the reports and correspondence revealed an unprecedented manipulation of science. Most remarkable, he says, was the contrast between an extremely sophisticated internal scientific effort, and what he described as the "junk" science encouraged by the company through outside grants. But he says that the papers also reveal that, over time, company lawyers were eventually able to exert control over internal projects as well.

The documents indicate that company scientists were decades ahead of mainstream researchers in understanding nicotine addiction, cancer, passive smoke, chronic bronchitis and the physics of smoke. But correspondence between company executives and their legal advisers suggest the

\section{IMAGE UNAVAILABLE FOR COPYRIGHT REASONS}

Lighting up: study claims that tobacco companies were way ahead in research.

lawyers sought to keep findings away from the scientific community and the public.

In their report, the UCSF researchers detail documents showing that tobacco company lawyers reviewed scientific manuscripts before they were published, sometimes changing the language or citations to serve the company's purposes. The report also suggests the lawyers tried to halt discussion of certain topics among scientific colleagues, warning that statements seeming to admit that smoking caused cancer or other disease would be harmful in court.

The 8,000 pages of documents include hundreds of examples of the vast difference between the internal world of tobacco industry research and the face that the companies present to the outside world. "It's our first crack in the wall to see what was really going on in these places," says Glantz, who led the months-long inquiry by five specialists into the documents' contents.

Sally Lehrman and instructions that placed political considerations ahead of scientific decisions," said the subcommittee chairman, John Edward Porter (Republican, Illinois), as he opened the vote on the massive spending bill for the Departments of Education, Labor, and Health and Human Services.

After discussing the issue with Arnold Levine of Princeton University, the head of OAR's evaluation team, Nancy Pelosi (Democrat, California), put forward an amendment to restore OAR's budget responsibilities. But it failed to win the necessary support of the subcommittee.

"If we start setting political priorities, there is no way to know where the money will go," said Robert Livingston, chair of the full appropriations committee, who attended the vote and expressed concern about attempts to single out AIDS research for special treatment.

"Heart, lung and blood diseases account for half of the deaths in this country, yet they receive only 7.2 per cent of NIH's budget," said Livingston. “We spend $\$ 295$ per patient on cancer research, $\$ 158$ per patient on multiple sclerosis, $\$ 93$ on heart disease, $\$ 54$ on Alzheimer's, \$26 on Parkinson's and \$36,000 per AIDS patient on research."

Under the subcommittee's bill, the NIH would receive an increase of $\$ 642$ million over its 1995 budget. This is a significant contrast to the $\$ 9.3$ billion in cuts and terminations that the bill would impose on social service programmes, including the elimination of 163 job training initiatives and 50 education programmes.

The National Cancer Institute would receive an increase of $\$ 114$ million, 5.3 per cent over 1995 levels, and the National Centre for Human Genome Research an extra $\$ 17$ million, to $\$ 170$ million.

The proposed budget increase for the NIH may be short-lived. The White House has made it clear that President Bill Clinton will not sign the bill unless at least some of the terminated programmes are reinstated.

But lobby groups keen to see the NIH budget increase, ranging from those representing patients' groups to pharmaceutical companies, are likely to put pressure on Clinton to sign. "You either take the money out of other programmes, or you take it out of NIH," says Dave Moore, of the Ad Hoc Group for Medical Research Funding, concerned that pressure to restore social programmes may mean a raid on NIH funding.

The level of AIDS research funding is not specified in the subcommittee bill. Both Porter and Livingston say this does not necessarily imply that AIDS research will be cut. But AIDS researchers believe otherwise, and have already drafted a letter of protest to Livingston.

The argument that removing the funding authority of OAR will not have any 
-impact is "nebulous", says John Moore of the Aaron Diamond AIDS Research Center in New York, chair of OAR's vaccine research and development committee. "If that is the case, why do it?"

The letter, drafted by Moore, says that before the creation of the OAR, the funding of AIDS research at NIH "was inefficient, leading to an uncoordinated, duplicated and disorganized allocation of federal funds".

Under the eye of Levine, the OAR is reviewing this system. It will report to Congress in September, in preparation for a major overhaul of the type of AIDS research undertaken at NIH. The scientists say Congress should delay any decision about the office until the report has been submitted.

But the panel's action has not come as a surprise. "We knew Republicans didn't hold OAR in favour," says Moore. Furthermore, he points out, the influence of AIDS activists with Republicans is considerably less than that of others fighting to defend the NIH budget.

Spencer Cox, of the Treatment Action Group in New York, says that his group is particularly concerned about the prospect that control over AIDS research funding will be returned to Anthony Fauci, director of the National Institute of Allergy and Infectious Diseases which conducts about half of AIDS research at NIH.

"Paul emphasizes basic, baseline research," says Cox, claiming that this contrasts with Fauci's earlier approach when he held sway over AIDS research funding at the institute. Cox's comments suggest that the latest congressional moves have rekindled the animosity previously directed at Fauci by some members of the AIDS community.

Adrianne Appel

\section{Serco wins physics laboratory contract}

London. Ian Lang, Britain's secretary of state for trade and industry, announced last week that a five-year contract to manage Britain's National Physical Laboratory NPL) has been awarded to a consortium led by Serco, a contract management group first created in 1929 by the US company RCA to manage its cinemas in Britain.

In a written statement to the House of Commons, Lang said that the consortium, which also includes AEA Technology and Loughborough University, will be expected to extend NPL's commercial work without compromising its status as a world centre of excellence in metrology.

Serco was bought out by its managers in 1987, and has grown rapidly as the government has privatized the management of public services. The defence industry accounts for 36 per cent of its business. But the group's other interests range from running a prison in Doncaster in the north of England to looking after 17,000 parking meters in Hong Kong.

\section{Major claims policy changes will 'strengthen' UK science}

London. The British government found itself having to fight hard last week to justify its decision to move the Office of Science and Technology (OST) out of the Cabinet Office and into the Department of Trade and Industry (DTI).

Faced with a continuing stream of protest from both the scientific and political communities, Ian Taylor, an under-secretary of state within the DTI and given responsibility for science and technology, said that the science office was being moved "closer to the effective heart of government".

Taylor, whose rank is usually referred to as that of junior minister, also dismissed concerns that the result would inevitably be a reduced commitment to longterm, fundamental research. His remarks came shortly UNAVAILABLE after John Major, the prime minister, had told the House of Commons that the purpose of the move was "to strengthen the con- Taylor: arrival received tribution of science, a cautious welcome. engineering and technology to long-term wealth creation."

But the scientific community remains suspicious. The pressure group Save British Science (SBS), for example, stayed on the offensive. One of its co-founders, Dennis Noble of the University of Oxford, criticized the move in a speech to the Physiological Society as "disastrous", claiming that it could, if handled insensitively, "quite simply strangle the creativity of the science base."

Within Parliament itself, criticism was not confined to the opposition Labour Party which said that it remained committed to an independent OST - but also came from the Conservative backbenches. In particular, Robert Jackson, who had been a junior minister in the Cabinet Office during the preparation of the government's white paper on science in 1993, wrote in an article in the Financial Times that the move represented "an alarming triumph of short-termism".

Taylor vigorously disputes such criticism, emphasizing the importance of assuring that "there is an interaction between what is happening in industry and what is happening in science", and thus the advantage to science - with its mission to improve the performance of the national economy and raise the quality of life - in being placed within the DTI.

Taylor was parliamentary private secretary to William Waldegrave, the cabinet minister responsible for science from 1992 to 1994 . He says that part of his role will be to convince industry of the importance of long-term, 'blue-sky' research. "This is the most exciting portfolio in government, and the one that has the greatest opportunities," he says.

In response to concern expressed by, among others, Sir Arnold Wolfendale, former astronomer royal and president of the Institute of Physics, over the future of the government's support for the public understanding of science - an increasingly significant role of the OST - Taylor says that it "fits in beautifully" with his current efforts to promote awareness of the importance of industrial innovation, for example among school science teachers.

Taylor's appointment has come as some relief to the scientific community. He was previously under-secretary of state for trade and technology, a position that included responsibility for DTI's involvement in topics such as information technology and space, and is widely seen as both conscientious and approachable.

"We certainly welcome Taylor as someone who looks as if he will take a serious interest in his responsibilities," says John Mulvey, secretary of SBS. Space scientists, responsibility for whose field had previously been split between the DTI and the research councils, have given the appointment a particular welcome.

But Mulvey and other critics also point out that, however great Taylor's enthusiasm, his powers as a junior minister - for example, in his ability to influence the research agendas of other government departments - are likely to be limited.

Furthermore, by allocating responsibility for science to what is widely seen as a "third rank" ministerial post, the government may, according to some observers, have made it difficult for the House of Commons Select Committee on Science and Technology to make the case for its continued existence.

Taylor himself says that he considers the committee - which could in principle disappear under a post-1992 rule that the responsibilities of such committees must mirror those of government departments, placing science under a broader trade and industry committee (see Nature 376, 103; 1995) - plays an important role in reviewing science related issues.

Sir Giles Shaw, Conservative MP for Pudsey and chairman of the committee, says he is optimistic that it will survive, partly because of its unique transdepartmental role, and partly because the long-term issues it tackles, such as human genetics (see page 202), are relatively non-political.

David Dickson 